\title{
DIGITAL MARKETING: PENGEMBANGAN KAPASITAS KEWIRAUSAHAAN PADA SARJANA MASA TUNGGU
}

\author{
Addin Kurnia Putri ${ }^{1}$, Supriyadi ${ }^{2}$, Mahendra Wijaya ${ }^{3}$, Sri Hilmi Pujihartati ${ }^{4}$, Thomas Aquinas Gutama \\ Universitas Sebelas Maret \\ email: ${ }^{1}$ addinkurniaputri@staff.uns.ac.id, ${ }^{2}$ supriyadi53@staff.uns.ac.id \\ ${ }^{3}$ mahendrawijaya_uns@yahoo.co.id, ${ }^{4}$ srihilmipujihartati@yahoo.co.id, ${ }^{5}$ gutama1109@gmail.com
}

\begin{abstract}
Abstrak
Perguruan tinggi sebagai produsen sumber daya manusia unggul menjadi poros utama dalam pengembangan kapasitas dan keterampilan mahasiswa, baik secara akademik maupun non-akademik. Lulusan perguruan tinggi sudah selayaknya menghasilkan tenaga-tenaga ahli di berbagai bidang industri. Meski demikian, jumlah pasar tenaga kerja tidak sebanding dengan permintaan tenaga kerja. Pasar tenaga kerja jumlahnya lebih terbatas dibanding permintaan tenaga kerja. Hal itu yang menyebabkan munculnya sarjana masa tunggu dikarenakan tidak langsung diterima di perusahaan tertentu. Maka dari itu, tujuan dari pengabdian ini adalah untuk meningkatkan semangat wirasuaha para sarjana masa tunggu di lingkungan Universitas Sebelas Maret. Konsep digital marketing digunakan untuk meningkatkan kapasitas wirasuaha sarjana masa tunggu sekaligus merespon perkembangan teknologi digital. Pengabdian ini menggunakan metode eksperimen dalam menguji kapasitas wirausaha sarjana masa tunggu sebelum dan setelah mengikuti pelatihan digital marketing. Hasil dari kegiatan tersebut menunjukkan bahwa pelatihan digital marketing berhasil meningkatkan kapasitas pengetahuan, kemampuan, dan keterampilan wirausaha pada sarjana masa tunggu, khususnya di lingkungan Universitas Sebelas Maret. Program aksi yang telah dilakukan adalah pelatihan penggunaan media sosial untuk pengembangan wirausaha kepada beberapa sarjana masa tunggu di antaranya adalah pemilik toko souvenir dan kue camilan.
\end{abstract}

Kata kunci: E-Marketing, kewirausahaan, peningkatan kapasitas

\section{PENDAHULUAN}

Permasalahan pengangguran merupakan permasalahan yang saat ini menjadi perhatian khusus pemerintah termasuk pemerintah daerah. Pengangguran akan mendorong timbulnya permasalahan sosial lainnya. Data BPS menyebutkan bahwa sepanjang tahun 2013 hingga 2017, tingkat pengangguran terbuka pendidikan tertinggi yang ditamatkan bergerak fluktuatif. Pada tahun 2013, tingkat pengangguran terbuka menurut pendidikan tertinggi yang ditamatkan Indonesia tercatat sebesar 7.410.931 jiwa, jumlah ini lebih besar dibanding periode sebelumnya. Selanjutnya pada tahun 2017, pengangguran terbuka untuk pendidikan tertinggi menurun menjadi 7.005.262 jiwa sedangkan lulusan sarjana sebesar 606.939 jiwa. Data tersebut menunjukkan memang adanya Teknologi Informasi dan Komunikasi 
penurunan jumlah pengangguran. Akan tetapi, jumlah pengangguran lulusan sarjana justru cenderung mengalami peningkatan dari tahun sebelumnya. Hal tersebut dapat diamati dari data grafik berikut ini:

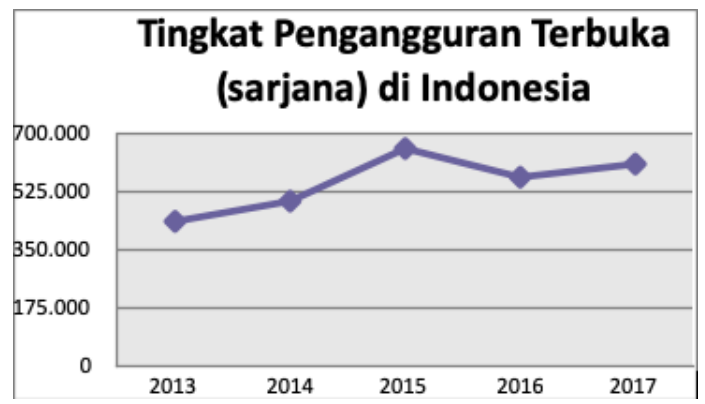

Gambar 1. Tingkat Pengangguran Terbuka menurut Pendidikan Tertinggi (Sarjana) Tahun 2013-2017. Sumber: BPS, 2017

Sedangkan di tingkat lokal, berdasarkan gambar 1.1 jumlah pengangguran di Kota Surakarta per Agustus 2017 mencapai 12.133 terdiri dari 6.553 laki-laki dan 5.580 perempuan. Dengan demikian tingkat pengangguran di Kota Surakarta mencapai $4,47 \%$. Tingkat pengangguran ini memang lebih rendah dibandingkan dengan tingkat pengangguran di Provinsi Jawa Tengah $(4,57 \%)$ dan nasional $(5,5 \%)$. Akan tetapi, berdasarkan Pusat Data dan Informasi Ketenagakerjaan, Kementerian Tenaga Kerja dan Transmigrasi (2017), jumlah lulusan sarjana yang menganggur di Kota Surakarta adalah sebesar 1.177 orang atau sebesar $9,70 \%$ dari total jumlah penganggur.

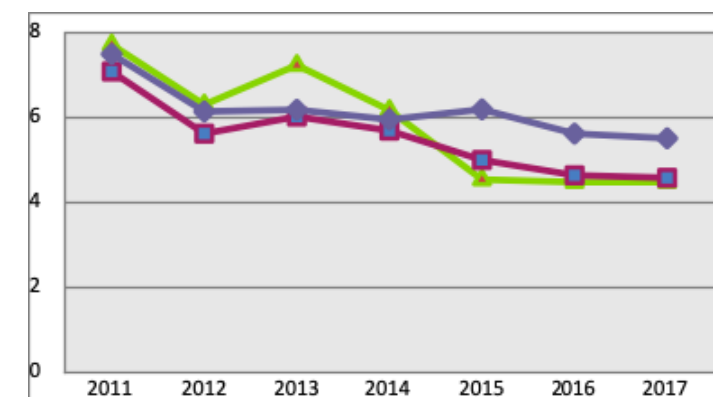

Gambar 2. Perbandingan Tingkat Pengangguran Tahun 2011-2017
Sumber: BPS Provinsi Jawa Tengah dan BPS Indonesia.

Melihat masih tingginya jumlah pengangguran tersebut tentunya perlu melakukan upaya-upaya, salah satunya dari pihak universitas. Universitas Sebelas Maret sebagai kampus negeri terbaik di Surakarta juga telah melakukan berbagai upaya untuk mengurangi angka pengangguran, dalam hal ini dengan menurunkan lama masa tunggu lulusan memperoleh pekerjaan. Salah satu upaya yang telah dilakukan adalah melalui kegiatan Job Fair yang rutin diadakan di kampus. Carier Development Center (CDC) Universitas Sebelas Maret (UNS) yang bertanggung menyelenggarakan Job Fair ini mengemukakan bahwa menurut hasil penelusuran terakhir masa tunggu lulusan UNS adalah 3,5 bulan. Penyelenggaraan Job Fair tersebut merupakan upaya CDC untuk membantu lulusan mendapatkan pekerjaan dan memperpendek masa tunggu lulusan.

Akan tetapi, lulusan sarjana sudah seharusnya juga diarahkan tidak sekedar mencari pekerjaan seperti melalui Job Fair. Lulusan perlu didorong untuk menciptakan lapangan kerja baru sebagai wirausaha sesuai dengan ketrampilan yang dimiliki.

Mitra program pengabdian ini adalah para sarjana masa tunggu. Peserta dari pelatihan digital marketing sarjana masa tunggu ini sebanyak 100 orang dari para alumnus Universitas Sebelas Maret. Tujuan dari pengabdian ini adalah untuk meningkatkan semangat wirausaha di kalangan sarjana masa tunggu akumnus Universitas Sebelas Maret. Khususnya dalam menghadapi persaingan global pada era digital seperti sekarang ini, sudah seharusnya lulusan sarjana juga memiliki jiwa wirausaha, bahkan sejak masih menjadi mahasiswa.

Manfaat yang diperoleh dari program pengabdian ini bagi mitra adalah meningkatkan kemampuan dan kreatifitas sarjana masa tunggu, khususnya dalam bidang digital marketing dan 
meningkatkan pendapatan ekonomi para sarjana masa tunggu.

\section{METODE}

Metode pelaksanaan pengabdian "Pelatihan E-Marketing Sarjana Masa Tunggu di Lingkungan Universitas Sebelas Maret, Surakarta" ini memakai metode partisipatif, yaitu tim pengabdian berpartisipasi aktif secara langsung dalam pelatihan sarjana masa tunggu. Sehingga melalui pendekatan partisipatif ini dapat mendorong kelompok sasaran untuk mampu mengidentifikasi, menganalisis, dan melakukan pemetaan masalah, potensi, ancaman, dan hambatan dalam dunia kewirausahaan.

Pelaksanaan kegiatan pengabdian masyarakat ini dilakukan melalui tahap-tahap pelaksanaan sebagai berikut:

\section{Penyadaran kelompok sasaran}

2. Brainstorming dan Focus Group Discussion (FGD) mendiskusikan pemikiran, pandangan dan pengalaman kelompok sasaran

3. Menyusun rencana program dan modul pelatihan bagi kelompok sasaran

4. Pelaksanaan program

5. Lokakarya yang dirancang bagi kelompok sasaran

6. Pendampingan kelompok sasaran

7. Evaluasi dan monitoring hasil pelaksanaan pengabdian.

\section{HASIL DAN PEMBAHASAN}

Pengangguran sampai saat ini masih menjadi masalah bagi semua negara di dunia. Dampak pengangguran tidak hanya bersifat ekonomis tetapi juga sosial dan psikologis. Semakin tinggi tingkat pengangguran, artinya semakin banyak sumber daya manusia yang tenaganya tidak dipakai. Tekanan ekonomi tersebut pada akhirnya akan mempengaruhi kehidupan sosial dan psikologis masyarakat.

Secara makro, pengangguran merupakan angkatan kerja yang sedang tidak mempunyai pekerjaan, sementara secara mikro pengangguran adalah mereka yang mampu dan mau melakukan pekerjaan akan tetapi sedang tidak mempunyai pekerjaan (Suroto, 1986: 12-13). Pengangguran juga didefinisikan sebagai angkatan kerja yang tidak memiliki pekerjaan atau belum memiliki pekerjaan dan sedang aktif mencari pekerjaan (Kusnendi, 2003: 203). Angkatan kerja yang bermaksud tidak mencari pekerjaan tidak tergolong sebagai pengangguran, namun termasuk golongan bukan angkatan kerja, contohnya ibu rumah tangga dan mereka yang sedang bersekolah. Pengangguran dapat dikatakan sebagai angkatan kerja yang tersisih dari mereka yang sudah memiliki pekerjaan. Menurut Coolidge (1930) semakin banyak orang yang terbuang dari pekerjaan, maka disitulah pengangguran dihasilkan (Borjas, 2008: 486).

Sarjana masa tunggu perlu memperoleh perhatian khusus. Berdasarkan hasil penelitian Astuti (2013), lama menganggur sarjana yang semakin panjang juga disebabkan oleh keinginan untuk memperoleh pekerjaan yang sesuai dengan pendidikan yang dimilikinya dan berharap memperoleh upah besar, untuk itu mereka lebih memilih menganggur sambil mencari kerja. Sedangkan lulusan yang memilih jenis pekerjaan wirausaha akan jauh lebih cepat bekerja, sehingga dalam hal ini universitas perlu memberikan pelatihan kewirausahaan kepada sarjana masa tunggu, dalam konteks P2M ini adalah pelatihan emarekting yang menjadi dasar dalam berwirausaha mandiri.

Revolusi industri 4.0 dan pertumbuhan teknologi di Indonesia terus mengalami perkembangan, hal ini didukung pula dengan adanya internet. Internet mendorong kepada seluruh pihak untuk tidak perlu melakukan tatap muka secara langsung dalam melakukan aktifitas kesehariannya, seperti mencari informasi, berkomunikasi, memberikan bantuan sosial, serta melakukan aktifitas belanja online pada marketplace-marketplace yang ada. Pengguna internet di Indonesia setiap tahun terus bertambah, menurut survei yang dilakukan oleh Asosiasi Penyedia Jasa Internet Indonesia (APJII) pada tahun 2017 mencatat adanya peningkatan dari 132, 7 juta

Teknologi Informasi dan Komunikasi 
jiwa pada tahun 2016 melonjak menjadi 143, 26 juta jiwa dari total 206 juta jiwa penduduk Indonesia (Buletin APJII, 2019).

Berkembangnya internet di Indonesia memberikan berbagai inovasi baru dalam kegiatan masyarakat seperti dengan bisnis, yakni ecommerce yang menjadi salah satu strategi industrialisasi digital marketing dengan memanfaatkan perkembangan teknologi, khususnya internat di mesin pencaharian Google. Menurut Celik dan Yilmaz (2011) e-commerce merupakan cara yang efektif untuk melakukan penjualan dan pembelian barang melalui jaringan internet.

Melihat peluang perkembangan teknologi informasi, media online dirasa sangat efektif digunakan untuk media pemasaran. Maka dari itu, perguruan tinggi dalam hal ini perlu menangkap peluang tersebut untuk meningkatkan semangat kewirasusahaan bagi lulusan. Untuk itu, salah satu upaya yang bisa dilakukan adalah dengan melakukan pelatihan E-Marketing bersama dengan praktisi. Pelatihan E-Marketing ini dilakukan secara daring dengan konsep webinar.

Sasaran program pengabdian ini adalah sarjana masa tunggu sebanyak 100 orang dari para alumnus Universitas Sebelas Maret. Oleh karena itu, pelatihan digital marketing dirancang untuk memberikan ketrampilan dasar sebagai modal sarjana masa tunggu menghadapi dunia kerja. Sarjana masa tunggu perlu didorong untuk tidak hanya mengandalkan pada lapangan pekerjaan. Lebih dari itu, mereka dapat menciptakan lapangan pekerjaan sendiri sesuai dengan kemampuan dan kreativitasnya. Riset eksperimen ini menguji beberapa indikator seperti pengetahuan digital marketing, memfungsikan website, memfungsikan media sosial, membidik pasar, memfungsikan marketplace, membuat kalimat promosi, dan membuat toko online sendiri.

Sebelum merancang program aksi, pengabdian ini melakukan eksperimen. Hasil pretest dari pelatihan digital marketing ini menujukkan bahwa peserta rata-rata hanya mengetahui perihal dunia digital marketing sebesar kurang dari $50 \%$ saja. Sementara dari hasil post-test menunjukkan bahwa peserta memahami digital marketing di atas
$50 \%$. Untuk lebih jelasnya dijelaskan pada gambar 3. berikut ini :

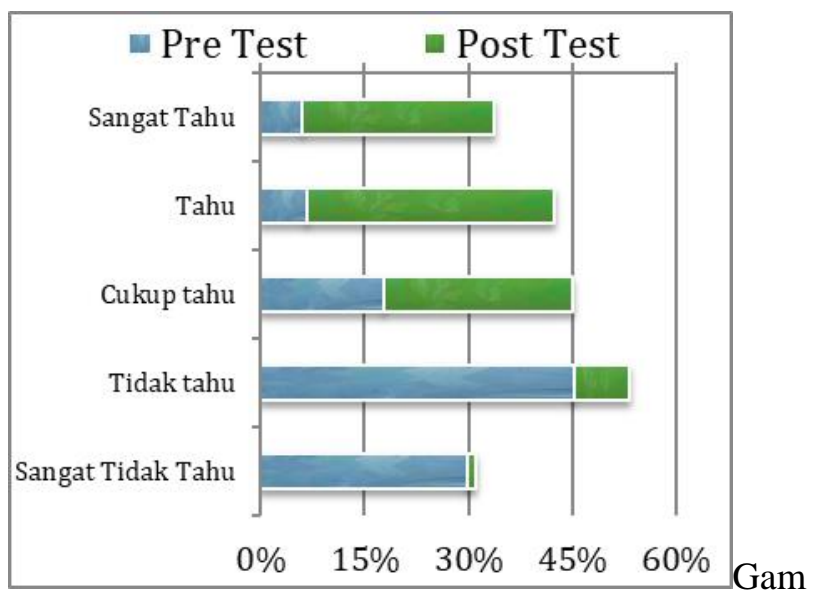

bar 3. Hasil PreTest dan Post Test Pelatihan Digital Marketing

Dari hasil pre test dan post test tersebut dapat dilihat bahwa terjadi kenaikan pengetahuan sebelum dan sesudah pelatihan. Pada saat pre test, pengetahuan peserta dengan kategori tidak tahu $(45,2 \%)$ dan sangat tidak tahu $(19,8 \%)$ paling dominan dengan total $75 \%$ dari total jumlah peserta. Kemudian setelah diberikan pelatihan, jika dilihat pada hasil post test maka terjadi kenaikan dari pengetahuan responden yaitu paling dominan pada kategori tahu $(35,6 \%)$, Sangat tahu $(27,8 \%)$ dengan total $63,4 \%$.

Program pengabdian ini dilakukan oleh para trainer ahli digital marketing seperti Nofi Bayu Darmawan dari Kampung Marketer dan Ahmad Mufid dari owner Moe Helm. Gambaran IPTEK program pengabdian yang dilaksanakan kepada mitra adalah sebagai berikut:

Tabel 1. Program Aksi Pengabdian Digital Marketing Sarjana Masa Tunggu

\begin{tabular}{|l|l|l|}
\hline & \multicolumn{1}{|c|}{ Seo Basic } & \multicolumn{1}{|c|}{$\begin{array}{c}\text { Monetiz } \\
\text { ing Models }\end{array}$} \\
\hline $\begin{array}{l}\text { Intro- } \\
\text { duction }\end{array}$ & $\begin{array}{l}\text { Memberikan intruksi } \\
\text { kepada peseta pelatahan } \\
\text { terkait dengan proses }\end{array}$ & $\begin{array}{l}\text { Secara } \\
\text { menyeluruh } \\
\end{array}$ \\
& memberikan \\
& dapat memberikan & pilihan \\
& peningkatan soft skill. & memperoleh \\
Mindset & Menjelaskan secara rinci & penghasilan \\
\hline
\end{tabular}

Nama Sub tema Penelitian 


\begin{tabular}{|c|c|c|}
\hline & $\begin{array}{l}\text { terkait dengan midset } \\
\text { membagun bisnis dengan } \\
\text { online marketing. }\end{array}$ & \multirow{6}{*}{$\begin{array}{l}\text { via online. } \\
\text { Baik untuk } \\
\text { Google Ads, } \\
\text { Menjual } \\
\text { Produk } \\
\text { Keratif yang } \\
\text { dapat } \\
\text { dilakukan, } \\
\text { dan Affiline. }\end{array}$} \\
\hline $\begin{array}{l}\text { Gathering } \\
\text { Nice and } \\
\text { Domain }\end{array}$ & $\begin{array}{l}\text { Proses diskusi dan } \\
\text { pemilihan domain untuk } \\
\text { membuat bisnis yang di } \\
\text { akan disebarkan via } \\
\text { online }\end{array}$ & \\
\hline $\begin{array}{l}\text { Keyword } \\
\text { Research } \\
\text { Content }\end{array}$ & $\begin{array}{l}\text { Proses pembelajaran } \\
\text { untuk memberikan } \\
\text { edukasi terkait cara } \\
\text { copywriter yang } \\
\text { dikolaborasikan dengan } \\
\text { SEO (search engine } \\
\text { optimization) atau } \\
\text { pengoptimalan mesin } \\
\text { telusur yang dilakukan } \\
\text { dalam Google }\end{array}$ & \\
\hline $\begin{array}{l}\text { Informatio } \\
\text { n } \\
\text { Building } \\
\text { Sites }\end{array}$ & $\begin{array}{l}\text { Memberikan proses } \\
\text { pembangunan website } \\
\text { yang baik agar dapat } \\
\text { dioptimalisasikan untuk } \\
\text { binis. }\end{array}$ & \\
\hline $\begin{array}{l}\text { Site } \\
\text { Setting }\end{array}$ & $\begin{array}{l}\text { Memberikan penjelasan } \\
\text { terkiat dengan setting } \\
\text { website yang baik. }\end{array}$ & \\
\hline $\begin{array}{l}\text { Google } \\
\text { Guidelines } \\
\text { For } \\
\text { Webmaste } \\
\text { r }\end{array}$ & $\begin{array}{l}\text { Pemilihan produk yang } \\
\text { dapat dijualbelikan } \\
\text { dengan melihat spesifik } \\
\text { website yang telah } \\
\text { dibagun. }\end{array}$ & \\
\hline
\end{tabular}

Program aksi yang telah dilakukan dari pengabdian ini adalah peningkatan wawasan pasar melalui digital marketing dari para sarjana masa tunggu di antaranya produsen souvenir dan kue camilan kukiku.
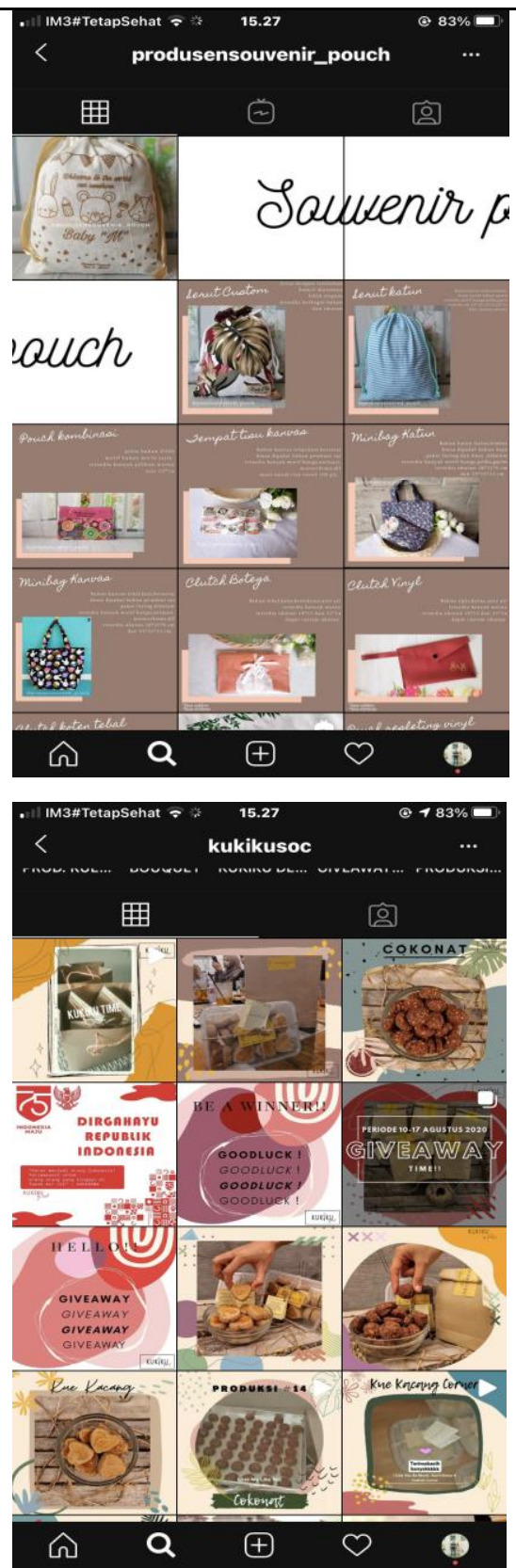

Gambar 4. Penerapan Digital Marketing pada Media Sosial Mitra Pengabdian

Beberapa usaha mitra yang telah menerapkan digital marketing adalah @ produsensouvenir_pouch dan @ kukikusoc di platform instagram. Dengan melakukan pemasaran secara digital, dua usaha milik mitra ini mampu menarik pasar lebih besar melalui online. 

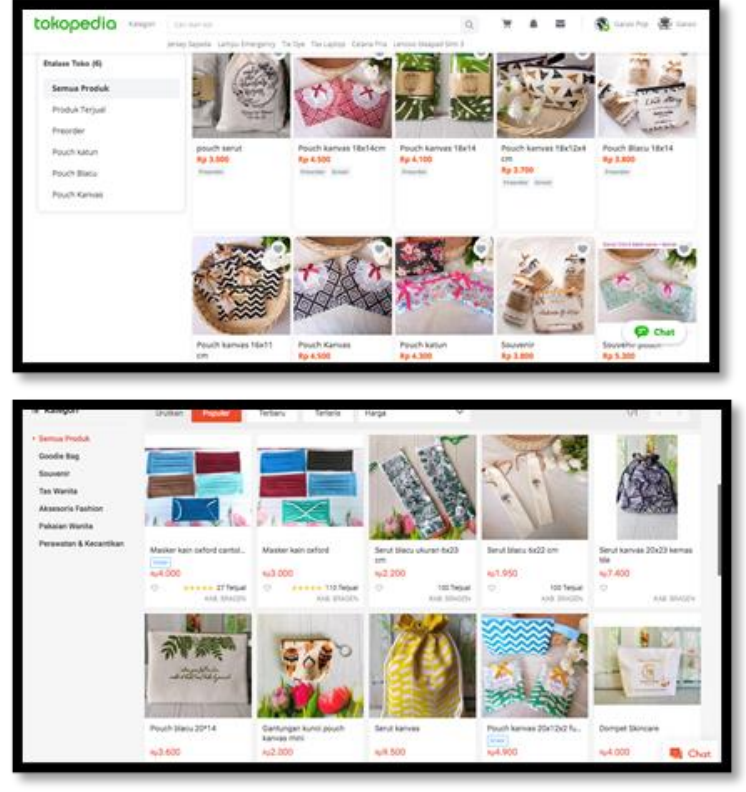

Gambar 5. Penerapan Digital Marketing pada Marketplace Mitra Pengabdian

Selain melalui media sosial, mitra juga menerapkan digital marketing melalui penjualan di marketplace Tokopedia dan Shopee. Dengan menerapkan penjualan di marketplace, ini telah berdampak pada wawasan pasar yang lebih luas dengan menerapkan prinsip SEO dalam digital marketing.

Potensi keberlanjutan dari program pengabdian ini adalah diharapkan mitra yang sudah sukses menerapkan digital marketing mampu melatih kemampuan dan keahlian tersebut kepada adik-adik tingkat atau lulusan sarjana masa tunggu setelahnya.

\section{KESIMPULAN}

Lulusan perguruan tinggi Indonesia yang memiliki gelar sarjana tidak lagi menjadi jaminan untuk mudah memperoleh pekerjaan. Daya serap lulusan sarjana dalam dunia kerja masih cukup rendah. Hal ini juga terlihat dari tingginya angka pengangguran lulusan sarjana. Oleh karena itu, perlunya pelatihan bagi sarjana masa tunggu agar tidak hanya sekedar mencari lapangan pekerjaan tetapi justru menciptakan lapangan pekerjaan sendiri dengan memaksimalkan ketrampilannya.
Salah satunya solusinya adalah dengan memberikan pelatihan e-marketing pada sarjana masa tunggu.

Berkembangnya internet di Indonesia memberikan berbagai inovasi baru dalam kegiatan masyarakat seperti misalnya bisnis e-commerce yang menjadi salah satu strategi industrialisasi digital marketing. Melihat potensi pemasaran dalam memanfaatkan internet tersebut, maka perlunya sarjana masa tunggu dapat memiliki soft skill untuk kemudian membangun bisnisnya sendiri. Hasil pelatihan E-Marketing ternyata mendapatkan dampak positif bagi sarjana masa tunggu. Sehingga perlunya keberlanjutan dari kegiatan semacam ini.

Rekomendasi program pengabdian ini adalah membentuk komunitas wirausaha dari lulusan Universitas Sebelas Maret sebagai wadah berjejaring, kerja sama, dan sinergitas dalam pengembangan kapasitas wirausaha, peningkatan ekonomi, dan kemandirian lulusan.

\section{REFERENSI}

Ariani, D. dkk. (2013). Analisis Faktor-Faktor yang Mempengaruhi Waktu Kelulusan Mahasiswa dengan Menggunakan Metode Gompit (Studi Kasus: Mahasiswa Fakultas MIPA Universitas Udayana). Jurnal E-Matematika,2 (3), 40-45. Badan Pusat Statistik, 2017.

Badan Pusat Statsitik. (2017). Laporan Badan Pusta Statisik Jawa Tengah.

Borjas, G. (2008). Labor Economics. Boston: McGraw-Hill.

Buletin APJII. (2019). Mengawal Integritas Era digital 2019. 28 April 2019. https://apjii.or.id/downfile/file/BULETINAPJI IEDISI33Januari2019.pdf

Celik Eray. H and Yilmas Veysel. (2011). Extending The Technology Acceptance Model For Adoption of E-Shopping By Consumers in Turkey. Journal of Electronic Commerce Research, Vol 12, No 2, Page 152164

Handayani, T. (2015). Relevansi Lulusan Perguruan Tinggi di Indonesia dengan Kebutuhan Tenaga Kerja di Era Global. Jurnal Kependudukan Indonesia, 10 (1), 53-64.

Hasana, S.M. (2012). Peluang dan Daya Saing Lulusan Pendidikan Ekonomi Universitas 
Negeri Yogyakarta di Pasar Tenaga Kerja Pegawai Negeri Sipil (PNS) Guru SMA Provinsi Daerah Istimewa Yogyakarta. Skripsi. Universitas Negeri Yogyakarta.

Kusnendi, dkk. (2003). Ekonomi Sumber Daya Manusia dan Alam. Jakarta: Pusat Penerbitan Universitas Terbuka.

Laporan Pusat Data dan Informasi Ketenagakerjaan, Kementerian Tenaga Kerja dan Transmigrasi, 2017.

Suroto. (1986). Strategi Pembangunan dan Perencanaan Tenaga Kerja. Yogyakarta: Gadjah Mada University Press.

Satrianti, Prhariezka. (2018). Tren Digital Marketing yang Harus Кати Ketahui. https://id.techinasia.com/8- tren-digital-marketingtahun-2018 